\title{
Aspectos relevantes para a sistematização do lucro da intervenção no direito brasileiro
}

\author{
Relevant aspects for the systematization of the profit of intervention in Brazilian law
}

Anderson Schreiber
Rodrigo da Guia Silva*

\section{Resumo}

O escopo fundamental do presente estudo consiste no delineamento de perspectivas para uma sistematização do lucro da intervenção no direito brasileiro. Nessa empreitada, assume-se como premissa metodológica a análise funcional das obrigações, a possibilitar a identificação de três regimes jurídicos obrigacionais gerais - o negocial, o reparatório e o restitutório. Na sequência, investigam-se as propostas de enquadramento dogmático do lucro da intervenção na disciplina da responsabilidade civil ou na disciplina da vedação ao enriquecimento sem causa, concluindo-se pela sua vinculação ao regime restitutório. Analisa-se ainda a possibilidade de cumulação das pretensões restitutória e reparatória e aventam-se, por fim, alguns parâmetros relevantes para a quantificação da obrigação de restituir o lucro da intervenção.

Palavras-chave: Lucro da intervenção. Obrigações. Enriquecimento sem causa. Responsabilidade civil.

\section{Abstract}

The fundamental scope of the present study is the delineation of perspectives of a systematization of the profit of the intervention in Brazilian law. The study assumes as a methodological premise the functional analysis of the obligations, to enable the identification of three general legal regimes of obligations - the executory, the reparatory and the restitutionary. In the sequence, it investigates the proposals of dogmatic framing of the profit of the intervention in the discipline of civil liability or in the discipline of the prohibition to unjustified enrichment, being concluded by its connection with the restitutyonary regime. It is also analyzed the possibility of cumulating the restitutionary and reparatory claims. Finally, some parameters relevant to the quantification of the obligation to return the profit of the intervention are explored.

Keywords: Profit of intervention. Obligations. Unjustified enrichment. Civil liability.

\section{Introdução: investigação do lucro da intervenção à luz da análise funcional das obrigações}

O desenvolvimento contemporâneo da teoria geral das obrigações encontra relevante desafio nas hipóteses reunidas sob o rótulo genérico de lucro da intervenção. Trata-se, em síntese essencial, de situações nas quais uma determinada pessoa aufere vantagem patrimonial a partir da exploração não autorizada de

Professor titular de Direito Civil da Universidade do Estado do Rio de Janeiro (UERJ). Doutor em Direito Privado Comparado pela Università degli Studi del Molise - Itália. Mestre em Direito Civil pela UERJ. Procurador do Estado do Rio de Janeiro. Advogado. Rio de Janeiro - RJ - Brasil. E-mail: schreiber@sdls.com.br.

** Doutorando e mestre em Direito Civil pela Universidade do Estado do Rio de Janeiro (UERJ). Membro do Instituto Brasileiro de Direito Civil (IBDCivil) e do Comitê Brasileiro da Association Henri Capitant des Amis de la Culture Juridique Française (AHC-Brasil). Advogado. Rio de Janeiro - RJ Brasil. E-mail: rodrigo.daguiasilva@gmail.com. 
bens ou direitos alheios. ${ }^{1}$ Tal vantagem patrimonial pode assumir qualquer uma das configurações típicas de enriquecimento (incremento do ativo, diminuição do passivo ou poupança de despesas). A doutrina tem procurado construir uma espécie de regime jurídico geral do lucro da intervenção, concentrando-se especialmente sobre a identificação do fundamento da sua eventual restituição e sobre a quantificação da obrigação de restituir porventura imposta ao interventor. ${ }^{2}$

Caso sempre lembrado em matéria de lucro da intervenção é aquele julgado, na experiência portuguesa, pelo Supremo Tribunal de Justiça por meio do Acórdão de 3 de abril de 1964: o proprietário de um terreno ribeirinho, situado à margem do Rio Dão, veio a constatar que os proprietários do terreno contíguo haviam subtraído duzentos e cinco pés de amieiro (árvore típica da região) e quinhentos caminhões de areia, razão pela qual Ihes dirigiu uma ação indenizatória, fundada na responsabilidade civil, no intuito de ver ressarcido o seu prejuízo. Em defesa, os proprietários do terreno vizinho alegaram, entre outros argumentos, que a ação natural do Rio Dão já havia restaurado a quantidade originária de areia do terreno. Tal argumento restou acolhido pelo Supremo Tribunal de Justiça, o qual reputou que somente em relação ao corte dos amieiros seria possível reconhecer dano indenizável. Já no tocante à areia removida pelos interventores, a Corte concluiu que a insubsistência da situação de desfalque patrimonial obstava a configuração de dano indenizável, de modo que somente restaria ao proprietário ajuizar outra ação fundada especificamente no enriquecimento sem causa (na modalidade de intervenção) dos vizinhos interventores (LEITÃO, 1996, p. 717).

Ainda a título ilustrativo, pode-se pensar na hipótese de utilização não autorizada de imagem alheia. Imagine-se, nesse sentido, que determinada sociedade empresária, no intuito de divulgar a sua recém-criada marca de cerveja, decide tentar contratar o cantor mais famoso do país para protagonizar a sua campanha publicitária. Suponha-se, contudo, que o artista recuse a proposta. Irresignada com a resposta negativa, a empresa divulga fotografias do cantor no centro da campanha publicitária, aludindo a suposta preferência do artista pela cerveja anunciada.

A hipótese ora descrita serve à enunciação de alguns questionamentos relevantes na presente matéria: quais serão (e em qual extensão) as obrigações impostas à empresa que interveio no direito à imagem do artista? A sua obrigação abrangerá apenas os lucros cessantes, limitando-se ao pagamento do cachê que o cantor teria auferido caso houvesse aceitado a proposta para ceder consensualmente (e onerosamente) a divulgação da sua imagem? Nesse caso, não se estaria, por via reversa, obrigando o artista a contratar? Seria possível impor à empresa, de alguma forma, a obrigação de restituir o lucro auferido a partir da campanha publicitária baseada na exploração não autorizada da imagem alheia? Em caso afirmativo, deveria ser restituído o lucro em toda a sua extensão ou apenas em alguma proporção ${ }^{3}$ Eis algumas das questões que precisam ser enfrentadas no âmbito do tema do lucro de intervenção.

O presente artigo não constitui o lócus adequado para o desenvolvimento de todas as questões levantadas pela doutrina no tocante ao regramento da problemática do lucro da intervenção. Destina-se

Assim conceitua Menezes Leitão (1996, p.688) no âmbito do sistema português: "A hipótese do lucro por intervenção diz respeito a situações em que alguém obtenha um enriquecimento através de uma ingerência em bens jurídicos alheios, especialmente em virtude do uso, fruição, consumo ou disposição desses bens. Verificado esse enriquecimento, e não tendo o titular à sua disposição outro meio de ser indemnizado ou restituído, coloca-se justamente a questão jurídica de lhe poder ser atribuída uma pretensão de restituição desse enriquecimento com fundamento no art. 473, n 1. O fim dessa pretensão será assim a recuperação da vantagem patrimonial que, de acordo com a repartição dos bens efectuada pela ordem jurídica, respeitava a outrem, consistindo a questão central do enriquecimento por intervenção de determinar se e em que medida a vantagem patrimonial obtida se pode considerar pertença de outrem". A conceituação preliminar ora aventada parece possibilitar, ao menos em linha de princípio, a configuração de lucro da intervenção na hipótese de exploração não autorizada de bem ou direito de caráter não estritamente individual. A resolução de tal situação de lucro da intervenção possivelmente demandaria a aplicação dos instrumentos disponibilizados pelo ordenamento para a tutela dos direitos coletivos lato sensu (abrangidos os direitos individuais homogêneos, os direitos coletivos stricto sensu e os direitos difusos), do que decorreria, por exemplo, conforme o caso, o reconhecimento de legitimidade ativa extraordinária e a destinação do montante da condenação a um fundo coletivo.

2 Para uma análise das dificuldades inerentes ao esforço de enquadramento dogmático das hipóteses de lucro da intervenção no direito brasileiro, v. Konder (2017, passim).

3 Na mesma linha de sentido, apontam-se alguns questionamentos gerais subjacentes à problemática do lucro da intervenção: "[...] o lucro obtido pertence ao interventor (aquele que se utiliza de bem ou direito alheio) ou ao locupletado (aquele cujo bem ou direito fora utilizado indevidamente)? Haveria o referido lucro sem a existência do dito direito locupletado ou sem a atuação do próprio interventor? Isto posto, pertenceria o lucro a ambos e, se sim, em que proporção para cada?" (KONDER; SAAR, 2017, p. 149). 
tão somente a tratar de algumas possíveis consequências, na presente matéria, da assunção da premissa metodológica atinente à qualificação funcional das obrigações no direito civil, com particular destaque para a análise funcional das obrigações vinculadas à vedação ao enriquecimento sem causa. A percepção das similitudes e distinções funcionais entre as diferentes espécies de obrigação permite a aplicação da normativa mais diretamente relacionada à específica obrigação com a qual se depara o intérprete, de modo a se atingir concretamente a satisfação dos interesses merecedores de tutela que estejam em jogo em cada hipótese. ${ }^{4}$ De fato, em matéria obrigacional, o interesse do credor $^{5}-$ a ser tutelado de acordo com o respectivo regime jurídico - parece passível de recondução, a depender da hipótese fática que originou a obrigação, da realização das expectativas nascidas de compromissos assumidos, da reparação dos danos causados ou da reversão de transferências patrimoniais injustificadas (NORONHA, 2013, p. 440).

Substancialmente, a análise funcional das categorias de obrigações tratadas pelo direito brasileiro parece tornar possível a sua sistematização em torno de três principais regimes (negocial, reparatório e restitutório), vinculados à ratio do surgimento da obrigação - negócio jurídico, dano injusto e enriquecimento sem causa. ${ }^{6}$ Há que se reconhecer, assim, uma tripartição funcional das obrigações, podendo-se apartar as funções executória (de um negócio legitimamente celebrado), reparatória (de um dano injustamente causado) e restitutória (de um enriquecimento injustamente auferido) (NORONHA, 2013, p. 439; MIRAGEM, 2011, p. 385). Registre-se que, naturalmente, um negócio jurídico pode prever obrigações de restituir - mais usualmente referidas como obrigações de restituir (ou devolver) coisa certa (SILVA, 1976, p. 153). ${ }^{7}$ A restituição relevante ao presente estudo, diversamente, é aquela funcionalmente direcionada não à promoção de um interesse contratualmente ajustado, mas sim à recomposição de um patrimônio injustificadamente beneficiado.

O esforço de sistematização ora empreendido permite concluir que a identificação do regime jurídico regente de certa relação obrigacional (sem prejuízo, por certo, à consideração do ordenamento jurídico como todo unitário aplicável a cada caso concreto) depende da vinculação funcional da específica hipótese de obrigação aos regimes fundamentais consagrados pelo direito brasileiro - os regimes negocial, indenizatório e restitutório. Desse modo, não basta que a atenção do intérprete esteja voltada para a enunciação formal das fontes possíveis das obrigações, uma vez que todo fato jurídico tem aptidão, em tese, para constituir, modificar ou extinguir relações jurídicas obrigacionais a depender da valoração atribuída pelo ordenamento (NORONHA, 2013, p. 367-368; 427). A polissemia da expressão "fontes das obrigações" não deve obscurecer, portanto, a percepção de que qualquer fato jurídico pode consistir em "fonte" de obrigações (no sentido de hipótese fática de incidência da norma), a atrair, conforme a função concretamente desempenhada, os regimes negocial, reparatório ou restitutório.

Em suma, o que parece ser mais importante na presente matéria é a investigação da função desempenhada por cada específica obrigação. A aludida premissa de análise funcional das obrigações

\footnotetext{
A destacar a relevância do estudo das fontes das obrigações para a definição do regime jurídico aplicável, veja-se a lição de Lodovico Barassi (1964, p. 1. Tradução livre): "A fonte na qual o vínculo obrigacional afunda as suas raízes sem ser um seu elemento constitutivo reage largamente, porém, sobre a disciplina jurídica da relação; as obrigações contratuais, por exemplo - além das normas gerais comuns a todas as obrigações (art. 1174-1320) - são sujeitas também a normas a elas particulares (art. 1321 seg.). Disso resulta a importância que a natureza da fonte tem para a relação obrigacional".

5 Faz-se menção às figuras do credor e do devedor em razão da consagração do seu uso na práxis nacional, sem qualquer prejuízo à premissa metodológica de que toda relação jurídica (inclusive a obrigacional) consiste, do ponto de vista subjetivo, em uma ligação entre centros de interesse (nesse sentido, v., por todos, Perlingieri (2008, p. 734 e ss.), e igualmente sem prejuízo à premissa metodológica de que a complexidade da relação obrigacional aponta para a multiplicidade de situações jurídicas subjetivas ativas e passivas atreladas a cada um dos centros de interesse (nesse sentido, v., por todos, Larenz (1958, p. 37). Para uma análise mais detida dos influxos dessas premissas metodológicas na compreensão do fenômeno obrigacional, ver Silva (2017, p. 48 e ss.).

6 Parte da doutrina trata do tema sob a ótica das fontes das obrigações. Assim, por exemplo, Eduardo Espínola (2005, p. 75-77): “O direito contemporâneo, por força das divergências legislativas, reconhece que o enriquecimento sem causa é uma fonte de obrigações, ao lado da declaração da vontade e do ato ilícito, obedecendo a um princípio geral, com requisitos característicos, sem prejuízo de algumas disposições especiais referentes a casos determinados". Para uma análise crítica das proposições teóricas que tratam o enriquecimento sem causa como fonte da obrigação, seja consentido remeter a Tepedino (2008, capítulo 1).

7 A partir de tal percepção, Aline de Miranda Valverde Terra (2017, p. 189) diferencia a obrigação de restituição do equivalente na hipótese de resolução contratual da obrigação convencional de restituir coisa certa: "Note-se que a conversão no equivalente pecuniário independe de a restituição in natura ter se impossibilitado com ou sem culpa do devedor. Não se aplicam à hipótese os artigos 238 e 239 do Código Civil, relativos à perda da coisa objeto da obrigação de restituir, dado que de dívida de restituição não se trata, e sim de restituição imposta pela desconstituição da obrigação contratada [...]".
} 
no direito civil repercutirá diretamente na compreensão da disciplina dispensada ao lucro da intervenção pelo sistema brasileiro. Destacam-se, a propósito, três principais repercussões da mencionada premissa metodológica, a serem analisadas individualmente neste estudo: (i) a definição do enquadramento jurídico do lucro da intervenção no direito brasileiro; (ii) a investigação sobre a possibilidade de cumulação das pretensões referentes ao lucro auferido pelo interventor e ao dano sofrido pelo titular do direito; e (iii) a elucidação de possíveis critérios de quantificação que se afigurem compatíveis com o enquadramento jurídico do lucro da intervenção.

\section{Enquadramento sistemático do lucro da intervenção: uma questão de responsabilidade civil ou de enriquecimento sem causa?}

Reconhecidas as três possíveis categorias de obrigações de acordo com as funções desempenhadas, importa investigar com qual delas o lucro da intervenção mais propriamente se relaciona. De pronto, afastase o lucro da intervenção das obrigações de fonte negocial, vez que a matéria tem como pressuposto lógico a intromissão não autorizada (i.e., sem qualquer liame causal com negócio jurídico prévio) em bens ou direitos alheios. Restam à investigação, portanto, as categorias atreladas à responsabilidade civil (reparação de danos injustos) e à vedação ao enriquecimento sem causa, em torno das quais se configura expressiva divisão da doutrina.

Sustenta-se, de um lado, que a intervenção em bem ou direito alheio gera dano indenizável, cujo montante deveria ser integrado pelo lucro ilegitimamente auferido pelo interventor. ${ }^{8} \mathrm{~A}$ partir de tal concepção, a responsabilidade civil despontaria como o mecanismo propício para a repressão à auferição de lucro por quem houvesse explorado desautorizadamente bem ou direito alheio. ${ }^{9}$ Afirma-se, ainda nessa linha, que a consideração das vantagens auferidas pelo autor de conduta danosa traduziria um terceiro método de cálculo do dano patrimonial, ao lado dos critérios tradicionais do dano (ou empobrecimento) real e daquele patrimonial (COELHO, 1970, p. 32, nota de rodapé n. 53).

Tal linha de entendimento, a enquadrar o lucro da intervenção no âmbito da responsabilidade civil, parece refletir-se diretamente na redação do inciso II do artigo 210 da Lei de Propriedade Industrial (Lei $n^{\circ}$ 9.279/1996). Referido dispositivo alude, entre os critérios para determinação dos lucros cessantes, aos "benefícios que foram auferidos pelo autor da violação do direito". Observa-se, assim, em ao menos uma hipótese, a consagração normativa expressa da proposição teórica que identifica a relevância do lucro auferido pelo interventor para a delimitação da indenização a ser paga em favor da vítima do dano injusto.

Tal opção legislativa poderia ser interpretada meramente como equívoco normativo, mas há que se registrar que a solução adotada pela legislação nacional no âmbito da disciplina das hipóteses de violações a direitos de propriedade industrial não traduz autêntica peculiaridade da experiência brasileira. Afigura-se possível, em realidade, destacar certa similitude com as experiências espanhola ${ }^{10}$ e alemã (LEITÃO, 1996, p. 720-721; FERREIRA, 2013, p. 28-32), em que também se verifica uma incorporação do critério referente

8 Pereira Coelho (1970, p. 34) relata, nessa direção, a proposta de Rodolfo Sacco (1959): "É ainda aqui que se enquadra a doutrina recentemente defendida por Sacco, o qual julga descobrir no sistema jurídico italiano um princípio geral de responsabilidade civil extracontratual que obrigaria o interventor a entregar ao titular do direito todo o lucro obtido. E tal obrigação seria independente da culpa do devedor, do enriquecido".

9 Não por acaso se identifica que a proposta de enquadramento do lucro da intervenção na seara da responsabilidade civil tende a estar acompanhada da expansão das funções de tal instituto para além da função basilar reparatória: "A sua ideia seria já, porventura, a de que só assim o procedimento do infrator teria uma sanção adequada e se preveniriam futuras infrações; e é sobretudo a partir daí - da acentuação, cada vez mais nítida na doutrina moderna, de uma função sancionatória e preventiva da responsabilidade civil ao lado da sua tradicional função reparadora ou reintegrativa - que se defende a obrigação de restituir o lucro" (COELHO, 1970, p. 33). A ilustrar a linha de entendimento que enquadra o lucro da intervenção no âmbito da responsabilidade civil, v., ainda, na doutrina contemporânea, Teffé (2015, passim). Para uma análise da controvérsia verificada nas doutrinas portuguesa e alemã acerca do reconhecimento de funções da responsabilidade civil para além da indenizatória no âmbito da problemática de fundo atinente ao lucro da intervenção, v. ABREU (2002, passim).

10 Destaca-se, a propósito, a similitude entre o referido artigo 210 da Lei de Propriedade Industrial brasileira e o artigo 140 da Ley de Propiedad Intelectual espanhola. Para uma análise detida da legislação espanhola sobre propriedade intelectual, marcas e patentes, a apontar certa confusão entre critérios de responsabilidade civil e de enriquecimento sem causa, v. (DÍEZ-PICAZO (1999, p. 54 e ss.). 
aos lucros do interventor pela disciplina própria da responsabilidade civil. Tamanha é a influência da aludida linha de entendimento no âmbito da propriedade industrial e intelectual que a doutrina - no Brasil e alhures - não raramente cogita a exportação do específico critério legal de quantificação dos lucros cessantes também para a seara da concorrência desleal (MICHELON JR., 2007, p. 202; GIANNOTTE, 2014, p. 620621). Questiona-se, a propósito, a viabilidade de imposição, ao agente econômico, da obrigação de restituir (integral ou parcialmente) o lucro que houver auferido a partir da prática de atos de concorrência desleal. ${ }^{11}$

A proposição teórica de absorção do lucro da intervenção pela disciplina da responsabilidade civil encontra-se refletida ainda em algumas decisões dos tribunais brasileiros. ${ }^{12}$ Emblemática, nesse sentido, é a decisão proferida pela Terceira Turma do Superior Tribunal de Justiça no julgamento do REsp 1.335.624/ RJ ${ }^{13}$ A situação fática remonta à conduta de Coca-Cola Indústrias Ltda. de veicular na mídia comercial de seu principal produto, o refrigerante Coca-Cola, propaganda na qual os ex-jogadores Bebeto, BiroBiro e Dario trajavam short e camisa de futebol nas cores verde e amarela, respectivamente, figurando em destaque o número 7 (sete) no verso da camisa de Bebeto. Irresignada pela veiculação da referida campanha publicitária sem sua prévia autorização, a Confederação Brasileira de Futebol (CBF) ajuizou ação de obrigação de fazer e não fazer cumulada com pedido de indenização, aduzindo ser titular do direito de uso, gozo, posse e propriedade dos uniformes, emblemas e símbolos da seleção brasileira de futebol. Naquele caso concreto, argumentou a CBF que Coca-Cola Indústrias Ltda. fizera uma "cópia disfarçada" do uniforme da seleção brasileira masculina de futebol utilizado na conquista da Copa do Mundo de 1994. Segundo o relato da petição inicial, o propósito fraudulento da parte ré se evidenciava pelo fato de a peça publicitária, além das inserções normais, ser veiculada nos momentos que antecediam os intervalos e sucediam o término dos jogos da seleção brasileira na Copa das Confederações de 2009 e nas eliminatórias da Copa do Mundo de 2010.

Em primeira instância, o juízo sentenciante julgou parcialmente procedente o pleito autoral para, confirmando os efeitos da tutela antecipada deferida, determinar que a parte ré se abstivesse de veicular, por qualquer meio, a peça publicitária que fazia menção "indireta" à seleção brasileira de futebol. Ambas as partes interpuseram recurso de apelação. Coca-Cola Indústrias Ltda. pugnou pela reforma da sentença para que prevalecesse a improcedência total dos pedidos formulados na petição inicial. A CBF, por sua vez, requereu a reforma parcial da sentença, para que se determinasse, conforme relato do acórdão proferido pelo Tribunal de Justiça do Estado do Rio de Janeiro (TJRJ), a "indenização por danos morais, indenização por danos materiais, a serem apurados em liquidação de sentença" e, por fim, a "devolução do lucro com enriquecimento ilícito".

A 15a Câmara Cível do Tribunal de Justiça do Estado do Rio de Janeiro concluiu, por unanimidade, pelo desprovimento do recurso de Coca-Cola Indústrias Ltda. e pelo provimento parcial do recurso da CBF, para "condenar a primeira apelante a pagar à (sic) segunda lucros cessantes, a serem apurados em

\footnotetext{
11 Tende-se a se encontrar resposta afirmativa sobretudo nas hipóteses de "concorrência por exploração": "Como regra geral, portanto, no direito comparado, o enriquecimento obtido pela prática concorrencial desleal não deve ser distribuído aos competidores. Estabelecida a regra geral, a doutrina, em especial a alemã, logo tratou de identificar alguns casos excepcionais. Canaris propõe que seja admissível a restituição do enriquecimento por intromissão nos casos que denomina 'concorrência por exploração', pois, nesses casos, haveria uma posição jurídica de vantagem especificamente atribuída ao titular de um direito. Esses casos cobririam, por exemplo, a utilização de um segredo industrial ou a pirataria de projeto e a violação de pactos de não concorrência” (MICHELON JR., 2007, p. 202-203). Em sentido semelhante, conclui-se, na doutrina portuguesa: "Daí que pareça apenas ser de admitir a restituição do enriquecimento sem causa quando são lesadas as normas relativas à concorrência desleal que se destinam a proteger interesses individuais, uma vez que só nestas se pode atribuir legitimidade a determinado lesado para exigir a restituição do enriquecimento obtido à sua custa" (LEITÃO, 1996, p. 759-760).

12 Pertinente, a propósito, a crítica formulada por Cláudio Michelon Jr. (2007, p. 203-204) ao comentar a hipótese de intervenção sobre direitos da personalidade: "O valor total da restituição devida nesses casos é normalmente quantificado pelos tribunais como sendo o valor daquilo que o interventor-enriquecido deveria ter despendido para obter a autorização que tornaria a intervenção legítima (com causa). Essa forma de quantificação tem a vantagem de ser mais fácil de aferir em casos concretos. Em que pese essa vantagem, a jurisprudência não vai bem ao utilizar esse critério, uma vez que o enriquecimento sem causa não é uma forma de ressarcir lucros cessantes, mas sim uma forma de restituir ao dono da imagem os lucros que foram obtidos a partir da sua imagem. [...] a forma de quantificação do enriquecimento não deve tomar em conta aquilo que o 'empobrecido' deixou de ganhar, mas sim o que o enriquecido lucrou a partir da imagem de outrem".

13 Para ulterior aprofundamento da análise da referida decisão, v., com ampla bibliografia, Silva (2016, passim).
} 
liquidação por arbitramento". ${ }^{14}$ Entendeu-se que a configuração de lucros cessantes decorrera do "uso indevido, por imitação, de uniforme e distintivo de propriedade da autora da ação, ora segunda apelante, em propaganda veiculada pela ré, primeira recorrente, visando obtenção de lucro". No tocante ao quantum indenizatório, concluiu-se que o mesmo deveria "corresponder ao que a autora/segunda apelante poderia ter ganhado, caso tivesse autorizado o uso de seu uniforme e distintivo, tendo-se em conta o que suas demais patrocinadoras lhe pagaram e considerando apenas o período em que efetivamente houve divulgação da propaganda". Vale destacar que o Tribunal não se referiu expressamente ao pleito de "devolução do lucro com enriquecimento ilícito".

Em face da referida decisão, veio a ser interposto Recurso Especial por Coca-Cola Indústrias Ltda. aduzindo, no que diz respeito ao cerne do presente estudo, que (i) "a CBF não deixou de lucrar nada com os comerciais da Coca-Cola (a CBF já tinha vendido antecipadamente a terceiros o direito de exploração comercial e somente estes terceiros poderiam ter sofrido alguma perda com os comerciais da Coca-Cola)", e (ii) não haveria ilícito perpetrado pela Coca-Cola ao realizar campanha publicitária valendo-se de camisas amarelas e calções verdes, representativas da nação brasileira, "exatamente porque estas marcas específicas, por lei, são de domínio público e descabe à CBF invadir a propriedade imaterial de todos os brasileiros e torná-la direito subjetivo da CBF". A propósito do segundo argumento exposto, buscou Coca-Cola Indústrias Ltda. sustentar que o alegado uso indevido da imagem da CBF não teria sido configurado em razão de as cores utilizadas na peça publicitária (camisa amarela e short verde) não coincidirem exatamente com as cores do uniforme oficial da seleção brasileira de futebol (camisa amarela e short azul - e não verde).

A Terceira Turma do Superior Tribunal de Justiça concluiu, por unanimidade, pelo desprovimento do Recurso Especial. ${ }^{15}$ Prevaleceu o entendimento de que a campanha publicitária relacionada ao refrigerante Coca-Cola não se limitou a utilizar as cores da bandeira nacional, tendo, ao revés, promovido "sua utilização dentro de um contexto que remete, de forma inequívoca, ao escrete canarinho, cuja titularidade dos direitos de imagem são pertencentes à CBF". No tocante à configuração de lucros cessantes, a Corte asseverou que o caso em comento não cuidava de lucros cessantes meramente presumidos, mas de "evidente prejuízo, pois, segundo a prática comercial usual, somente patrocinadores oficiais obtêm autorização para a utilização da imagem da seleção brasileira de futebol". O STJ relegou, por fim, o arbitramento do referido prejuízo à fase de liquidação, sob a alegação de que, embora os ajustes de patrocínio com terceiros sirvam como ponto de partida para o arbitramento da indenização, "não há qualquer determinação para que sejam considerados [...] os valores globais daquelas contratações, mormente porque, não se pode também deixar de reconhecer, elas envolvem inúmeros outros direitos além daquele que foi usurpado no presente processo".

As decisões proferidas no caso, bem como os argumentos aduzidos pelas partes desde a primeira instância, revelam a expressiva tendência, na práxis brasileira, de associação imediata entre lucro da intervenção e lucros cessantes. Sem embargo dos possíveis êxitos em termos pragmáticos, referida tendência

14 RIO DE JANEIRO. TJRJ, AC. 0383190-62.2009.8.19.0001, 15a C.C., Rel. Des. Celso Ferreira Filho, julg. 07.06.2011, publ. 13.06.2011. O acórdão restou assim ementado: "Ação de Indenização. De Uso Indevido, Por Imitação, de Uniforme e Distintivo de Propriedade da CBF/Autora da Ação. Sentença de Procedência Parcial do Pedido, Confirmando a Tutela Antecipada Anteriormente Deferida. Agravo Retido Prejudicado, tendo em vista a apreciação do mérito da apelação nesta oportunidade. Propaganda utilizando os ex-jogadores Bebeto, Biro-Biro e Dario trajando vestimenta bem parecida com o uniforme da Seleção Brasileira, constando o número sete na camisa do jogador Bebeto. Propaganda que induz o expectador a levar em consideração a idéia de sucesso da seleção para a bebida Coca-cola. Obrigação de indenizar da primeira apelante, pelo uso indevido, por imitação. Lucros Cessantes que se reconhecem e que necessitam ser liquidados por arbitramento. Danos emergentes não comprovados, descabendo reconhecê-los por presunção. Inocorrência de dano moral. Sucumbência da primeira apelante estabelecida em conformidade com o artigo 21, parágrafo único, arbitrando-se os honorários em $10 \%$ sobre o valor da condenação. Desprovimento do Primeiro Apelo e Provimento Parcial do Segundo Recurso".

15 BRASIL. STJ. REsp. 1.335.624/RJ, 3ª T., Rel. Min. Ricardo Villas Bôas Cueva, julg. 05.12.2013, DJe 18.03.2014. A decisão restou assim ementada: "Recurso Especial. Responsabilidade Civil. Indenização. Utilização não autorizada de imagem da Seleção Brasileira de Futebol. Negativade Prestação Jurisdicional Afastada. Intuito Exclusivamente Infringente dos Embargos de Declaração. Lucros Cessantes. Contratos firmados com Patrocinadores Oficiais. Mero Parâmetro para Aliquidação por Arbitramento. Antecipação do Exame de Matérias relativas à Liquidação do Julgado. Impossibilidade. [...] 4. Não trata o caso da apropriação da camisa e da bandeira nacional, mas da sua utilização dentro de um contexto que remete, de forma inequívoca, ao escrete canarinho, cuja titularidade dos direitos de imagem são pertencentes à CBF. 5 . Também não cuida a hipótese de mera presunção de lucros cessantes, circunstância que a jurisprudência consolidada nesta Corte Superior repudia, mas de evidente prejuízo, pois, segundo a prática comercial usual, somente patrocinadores oficiais obtém autorização para a utilização da imagem da seleção brasileira de futebol. [...] 7. Recurso especial não provido". 
de resolução da problemática do lucro da intervenção na seara da responsabilidade civil parece decorrer, no que mais diretamente importa ao presente estudo, de certa dificuldade na promoção de análise funcional para a qualificação das obrigações no direito civil. Com efeito, uma vez assentada a distinção funcional das obrigações (e dos respectivos regimes jurídicos), conforme o perfil funcional promovido em cada caso, podese observar certa imprecisão conceitual na inclusão das vantagens auferidas pelo interventor no processo de quantificação da indenização devida à vítima de um dano injusto, tal como sucede no artigo 210, inciso II, da Lei de Propriedade Industrial (MICHELON JR., 2007, p. 201-202). Reconhece-se, em suma, que a "pretensão ao lucro da intervenção e a pretensão indenizatória são [...] coisas fundamentalmente diferentes" (SCHULZ, 1909, p. 457). ${ }^{16}$

Passa-se, então, ainda no esforço de compreensão do enquadramento jurídico do lucro da intervenção, à investigação da proposta teórica de aplicação da disciplina do enriquecimento sem causa. Sustenta-se, em oposição ao entendimento que incorpora o lucro da intervenção à delimitação do dano indenizável, que a imposição da sua restituição traduziria, do ponto de vista funcional, a preocupação em restaurar o patrimônio do interventor ao estado em que deveria estar caso não se houvesse verificado o fato gerador do enriquecimento (DÍEZ-PICAZO, 1999, p. 50).

A proposição de enquadramento do lucro da intervenção no âmbito do enriquecimento sem causa protagonizou a atenção da doutrina especializada na controvérsia referente à possibilidade ou não de tratamento unitário do instituto. Parte da doutrina sustenta a necessidade de divisão da temática, pugnando pela impossibilidade de recondução das variadas hipóteses de restituição a um fenômeno unitário. ${ }^{17}$ Formulou-se, assim, uma bipartição fundamental entre o enriquecimento obtido a partir de uma prestação do "empobrecido" e o enriquecimento obtido a partir de outros modos, inserindo-se o lucro da intervenção nessa segunda categoria. ${ }^{18}$ Tal via de compreensão do fenômeno restitutório parece se manifestar, na doutrina contemporânea, nas propostas teóricas que apontam a suposta ausência de fundamento comum e, sobretudo, a ausência de similitude entre as disciplinas normativas decorrentes da cláusula geral de restituição por enriquecimento sem causa, contida no artigo 884 do Código Civil brasileiro, e o regramento de institutos específicos, como a gestão de negócios e o pagamento indevido, também animados pela função restitutória.

Outra parcela da doutrina defende a configuração unitária do instituto do enriquecimento sem causa, sustentando que as diversas hipóteses de restituição, ainda que não idênticas em sua eventual disciplina normativa, seriam passíveis de recondução a princípios comuns. ${ }^{19} \mathrm{O}$ desenvolvimento de tal linha de

16 Tradução livre do original: "Der Anspruch auf den Eingriffserwerb und der Schadenersatzanspruch sind [...] grundverschiedene Dinge”.

17 Relata-se, nesse sentido, a proposta da pandectística de divisão do instituto do enriquecimento sem causa: "A pandectística efectuou assim uma violenta crítica à concepção de que o postulado de que ninguém deveria enriquecer-se à custa de outrem pudesse constituir a base de uma acção independente de enriquecimento, fosse ela a actio de in rem verso utilis ou a actio in factum wegen Bereicherung. Savigny defendeu expressamente que o princípio da proibição do enriquecimento à custa de outrem tinha uma natureza tão geral e indeterminada, que não admitia a sua aplicação directa à resolução de questões jurídicas concretas, podendo apenas ter influência na formação de algumas regras jurídicas precisas. A pandectística considerou assim este postulado excessivamente geral e indeterminado para poder ser aplicável directamente como proposição jurídica, o que obviamente impedia a construção de qualquer acção genérica de enriquecimento, mesmo que exclusivamente de aplicação subsidiária" (LEITÃO, 1996, p. 342).

18 Relata-se que a concepção de divisão do instituto, tributária originariamente da pandectística, foi retomada com vigor por Walter Wilburg e Ernst von Caemmerer: "A tese principal destes autores reside na divisão do $\S 812$ Ads. 1. S. 1 BGB em duas facti species relativas às condictiones com base numa prestação (durch die Leistung eines anderen) e as condictiones não baseadas numa prestação (auf dessen Kosten in sonstiger Weise), na qual se atribui papel preponderante à Eingriffskondition. Esta doutrina da divisão do instituto rompe completamente com o tratamento dogmático unitário do enriquecimento sem causa, que deixa inclusive de ser considerado como sujeito a princípios comuns ou a uma mesma ordenação sistemática" (LEITÃO, 1996, p. 411). Relata-se, ainda a propósito da experiência alemã: "Na esteira de Wilburg e de Von Caemmerer, a opinião largamente dominante na Alemanha é aquela que nega, radicalmente, a unidade do instituto e contradistingue o enriquecimento obtido através de uma prestação e o obtido 'por outro modo"' (GOMES, 1998, p. 197).

19 Menezes Leitão (1996) relata a proposta doutrinária alemã de configuração unitária do enriquecimento sem causa, em oposição às proposições de divisão do instituto: "Em oposição à corrente majoritária na doutrina, surgiu na Alemanha toda uma nova série de autores que questionou a moderna doutrina da divisão do instituto e pretende o regresso a uma fórmula unitária, através da ultrapassagem da estrita diferenciação entre a Leistungskondition ["condictio baseada em uma prestação"] e a Nichtsleistungskondition ["condictio não baseada em uma prestação"]. [...] De acordo com esta concepção o Tatbestand do enriquecimento sem causa é o mesmo em todos os grupos de casos da Leistungskondition e da Nichtsleistungskondition [...]. O que seria decisivo seria a aquisição em desconformidade ao Direito de um benefício a partir de um património alheio" (LEITÃO, 1996, p. 431-432). Prossegue o relato: "A unidade dos pressupostos do enriquecimento reside na exigência, em primeiro lugar, de que ocorra o enriquecimento de alguém, o enriquecido, segundo, que o enriquecimento provenha do património de outrem, o empobrecido, e, terceiro, que o enriquecido não tenha em relação ao empobrecido uma causa jurídica" (LEITÃO, 1996, p. 432). No que tange à proposta de reconhecimento da unidade do instituto, v., entre outros, Caperochipi (1979, p. 71 e ss.). 
entendimento deve-se, em larga medida, aos estudos de Fritz Schulz, ${ }^{20}$ que buscou identificar na violação de um direito alheio a razão comum à deflagração do mecanismo restitutório nas suas diversas manifestações, independentemente de envolver ou não uma prestação daquele à custa de quem se enriqueceu (LEITÃO, 1996, p. 407; GOMES, 1998, p. 180-181). Ainda a partir da referida premissa teórica de configuração unitária do enriquecimento sem causa, desenvolveu-se a noção de que o fundamento unificador do instituto residiria não propriamente na violação de um direito alheio (circunstância essa comum e provável, porém não necessária para a configuração do enriquecimento sem causa), mas, sim, na doutrina do conteúdo da destinação (Zuweisungsgehaltlehre) (BARBOSA, 2005, p. 589-591). Haver-se-ia de reconhecer enriquecimento sem causa, segundo tal formulação, quando a incidência do mecanismo restitutório tivesse por finalidade precípua assegurar a adequada variação patrimonial conforme a destinação jurídica dos bens. ${ }^{21}$

Sem embargo dos méritos de cada uma das proposições teóricas que buscaram elucidar a configuração unitária ou fracionada do instituto do enriquecimento sem causa, uma solução talvez mais segura, à luz da metodologia civil-constitucional, pode vir a ser fornecida pela já referida proposta de análise funcional das obrigações no direito civil. As relações obrigacionais parecem passíveis de recondução a regimes jurídicos gerais de acordo com a função desempenhada por cada espécie de obrigação. Enunciou-se, a partir de tal premissa metodológica, a tripartição das obrigações conforme os perfis funcionais mais comumente verificados - o perfil funcional executório, o reparatório e o restitutório. Justifica-se, a partir de tais premissas, o reconhecimento da configuração unitária do instituto do enriquecimento sem causa em torno da identidade de perfil funcional restitutório das variadas obrigações de restituição (decorrentes ou não da cláusula geral do dever de restituir), a justificar, como já destacado, a incidência de um tratamento uniforme e sistemático, ainda que não necessariamente idêntico.

As precedentes considerações permitem, enfim, explicitar o adequado enquadramento jurídico do lucro da intervenção no direito brasileiro. Trata-se de modalidade de enriquecimento sem causa, caracterizada pela exploração não autorizada de bem ou direito alheio. ${ }^{22}$ Tamanha é sua relevância na conformação dogmática do instituto que, sem embargo da compreensão previamente enunciada acerca da sua configuração unitária, apontam-se duas modalidades fundamentais de enriquecimento sem causa: o enriquecimento por prestação e o enriquecimento por intervenção. A restituibilidade do lucro da intervenção dependerá seja de uma previsão específica de restituição, seja da cláusula geral do dever de restituir. Assumindo-se a inexistência de uma previsão expressa (ao menos em termos genéricos) capaz de abranger as hipóteses de lucro da intervenção - o que traduz o respeito à regra da subsidiariedade contida no artigo 886 do Código Civil -, a

20 A destacar a importância da obra de Fritz Schulz para a reformulação da doutrina unitária tradicional do enriquecimento sem causa mediante a sua aplicação ao problema do lucro da intervenção, afirma-se: "A tradicional doutrina da concepção unitária do enriquecimento sem causa entra, porém, em crise após o surgimento da obra de Fritz Schulz, System der Rechte auf den Eingriffserwerb, onde o autor coloca pela primeira vez a questão jurídica da aplicação do instituto ao problema do lucro por intervenção" (LEITÃO, 1996, p. 402-403). Prossegue o relato: "Fritz Schulz parte igualmente de uma concepção unitária do instituto do enriquecimento sem causa, mas ao contrário da doutrina tradicional, orientada quase exclusivamente para as deslocações patrimoniais tendo por base uma prestação (Leistungskondition) o autor centra a sua atenção no problema da intervenção em bens ou direitos alheios, defendendo a aplicação nesta hipótese do instituto do enriquecimento sem causa. Esta solução implica o surgimento da Eingriffskondition, de que o autor pode justamente ser considerado o fundador, embora ele nunca tenha colocado em questão a unidade do instituto do enriquecimento sem causa, defendendo apenas uma sua reformulação dogmática" (SCHULZ, 1909, p. 403). Vale registrar que, segundo a formulação de Fritz Schulz, haver-se-ia de reconhecer uma possibilidade de escolha, pelo credor, entre a pretensão indenizatória e a pretensão restitutória (SCHULZ, 1909, p. 457). Pertinente, a propósito, o relato de Júlio Gomes (1998, p.183): "Para Schulz o parentesco entre a pretensão de entrega do lucro da intervenção e a obrigação de indenizar estaria em que ambas pressupõem, em regra, uma intervenção ilícita na esfera jurídica alheia [...], mas o nascimento desta última não exclui a gênese ou aparecimento simultâneo da primeira. De acordo com a visão deste autor, existe um concurso de pretensões, cabendo ao credor a escolha da pretensão que quer fazer valer".

21 Critica-se, em doutrina, a insuficiência da teoria de Fritz Schulz em razão da tutela excessiva e injustificadamente atribuída ao titular do direito com base na interpretação desmesurada da doutrina do conteúdo da destinação: "O problema do lucro da intervenção teve sua primeira exposição por Fritz Schulz e a solução dada por ele mostrou-se aquém do desejado; para ele, todo o lucro deveria ir ao locupletado, pois foi seu direito ou seu bem a gênese desse entrelaçamento patrimonial indesejado. Contudo, esta solução foi reputada como excessiva defesa do locupletado, de forma a gerar um novo enriquecimento sem causa a partir do saneamento de outro" (KONDER; SAAR, 2017, p. 149-150).

22 A sustentar que o instituto do enriquecimento sem causa não teria o condão de esgotar o enquadramento dogmático do lucro da intervenção, para o qual se haveria de reconhecer uma pluralidade de estatutos normativos. (KONDER, 2017, item 4). 
sua restituibilidade dependerá da concreta demonstração dos demais pressupostos (in casu, os positivos) da cláusula geral contida no artigo $884 .^{23}$

O enriquecimento do interventor, no sentido de vantagem patrimonial efetiva (e não virtual ou hipotética) poderá consistir, segundo o entendimento geral delineado em doutrina, no incremento do ativo, na diminuição do passivo ou na poupança de despesa, modalidades às quais parecem passíveis de recondução as mais variadas hipóteses fáticas do fenômeno (NANNI, 2010, p. 237; CORDEIRO, 2010, p. 224-226; SACCO, 1959, p. 196-200; CARBONNIER, 2004, p. 2.436; SIMLER; LEQUETTE, 2013, p. 1.114-1.115). Parece possível destacar, ainda nesse ponto, uma maior recorrência fática das hipóteses de incremento do ativo e de diminuição do passivo, como sucede, respectivamente, nos habituais exemplos da sociedade empresária, que alavanca as suas vendas a partir da utilização não autorizada da imagem alheia e da pessoa que invade e desfruta de casa de praia durante o período de viagem do seu proprietário. A obtenção à custa de outrem, por sua vez, se depreende da percepção de que a vantagem do interventor decorre, em maior ou menor extensão, do bem ou direito sobre o qual incidiu a intervenção. Ressalte-se, por oportuno, que o grau de contribuição causal do direito sobre o qual se interveio e da conduta do interventor repercutirão diretamente sobre a quantificação da obrigação restitutória (LINS, 2016, p. 189; SILVA, 2016, p. 15-16). A ausência de justa causa, por fim, é indiciada pela constatação da inexistência de autorização legal ou negocial para a utilização do direito alheio, sendo certo, contudo, que a ausência de título jurídico formal deve ser sopesada com os demais valores relevantes para a delimitação da (in)justiça do enriquecimento em cada caso concreto. ${ }^{24}$ Em realidade, deve-se reconhecer que a configuração do requisito da ausência de justa causa para fins de deflagração do dever de restituir o lucro da intervenção (como, aliás, da generalidade das hipóteses de enriquecimento sem causa) não se perfaz com a mera análise da inexistência de título jurídico em sentido formal e tradicional. Afigura-se imprescindível, ao revés, a promoção do juízo de merecimento de tutela para que se possa concluir sobre a justiça ou injustiça do enriquecimento à luz da legalidade constitucional (SILVA, 2017, item 2.3).

\section{Cumulatividade das pretensões restitutória e reparatória}

Analisadas algumas perspectivas de enquadramento sistemático do lucro da intervenção à luz da premissa teórica de qualificação funcional da pretensão restitutória, passa-se à análise de uma segunda ordem de repercussões da referida premissa. Investiga-se, doravante, a possibilidade de cumulação das pretensões referentes à restituição do lucro auferido pelo interventor e à reparação do dano sofrido pelo titular

23 A partir de semelhante linha de entendimento, a 13ª Câmara Cível do Tribunal de Justiça do Estado do Rio de Janeiro, ao apreciar hipótese fática de utilização indevida da imagem alheia, determinou a restituição de parcela do lucro auferido pelo interventor, com fundamento na vedação ao enriquecimento sem causa (TJERJ, Processo nº 0008927-17.2014.8.19.0209, 13 a C.C., Rel. Des. Fernando Fernandy Fernandes, julg. 26/10/2016, publ. 31/10/2016). Afirma-se, em análise da referida decisão, que ela haveria firmado "[...] um precedente aparentemente inédito no ordenamento jurídico brasileiro" (KONDER, 2017).

24 "A noção de título jurídico idôneo, de fato, serve como valioso parâmetro interpretativo, mas não parece recomendável que o intérprete resuma a análise à presença ou não de justo título tal como tradicionalmente concebido. Em vez disso, afigura-se mais razoável entender que o enriquecimento somente poderá ser considerado sem causa quando sobre ele incorrer juízo de reprovabilidade à luz da tábua axiológica constitucional. Desse modo, ainda que careça de justo título em sentido estrito, a situação jurídica do enriquecido pode vir a ser resguardada caso se conclua, diante das circunstâncias do caso concreto, que satisfatoriamente promove os princípios e valores do ordenamento" (SILVA, 2017, p. 17). Tal compreensão parece explicar a preocupação, verificada em doutrina, no sentido de que a problemática do lucro da intervenção suscitaria maior atenção ao requisito da obtenção à custa de outrem do que ao requisito da ausência de justa causa. Veja-se, ilustrativamente: "No âmbito do enriquecimento por intervenção, uma vez rejeitada a doutrina que configurava a ausência de causa jurídica através da ilicitude da intervenção, parece produtivo o recurso ao conceito de conteúdo da destinação dos direitos, considerando-se que uma aquisição não tem, em princípio, causa jurídica quando resulta na apropriação de bens ou utilidades destinadas a outrem através de um direito subjetivo ou de uma norma de proteção com um conteúdo patrimonial. Simplesmente, uma conclusão desse tipo implica fazer resultar automaticamente a ausência de causa jurídica a partir do requisito da obtenção do enriquecimento à custa de outrem no âmbito do enriquecimento por intervenção, o que implica deixar de atribuir relevo dogmático a este conceito nesta categoria de enriquecimento sem causa" (LEITÃO, 1996, p. 894-895). O autor arremata: "É, efetivamente, preciso reconhecer que o elemento central no âmbito do enriquecimento por intervenção reside antes na obtenção do enriquecimento à custa de outrem, o que atribui ao conceito de ausência de causa jurídica um significado mais rudimentar, pelo que, demonstrado que alguém se ingeriu no conteúdo da destinação de uma posição juridicamente protegida do empobrecido, há apenas que averiguar se no âmbito das relações jurídicas entre enriquecido e empobrecido, existe alguma situação que legitime a manutenção do enriquecimento na esfera do enriquecido, como, por exemplo, um contrato celebrado, a posterior aprovação da conduta, ou uma permissão legal de ingerência" (LEITÃO, 1996, p. 895). 
do direito. Perquirir a possibilidade de cumulação das pretensões restitutória e reparatória pressupõe, do ponto de vista metodológico, reconhecer que tais pretensões remetem a institutos funcionalmente distintos e não excludentes que, portanto, podem coexistir em uma mesma situação fática. Em atenção à função precípua da responsabilidade civil e da vedação ao enriquecimento sem causa, pode-se enunciar, desde logo, a regra geral segundo a qual as pretensões em comento coexistirão quando houver dano injusto a indenizar e enriquecimento injustificado a restituir.

A civilística contemporânea fornece exemplo a um só tempo controverso e emblemático para a discussão atinente à possibilidade de cumulação das pretensões restitutória e reparatória. Trata-se do fenômeno denominado inadimplemento eficiente, entendido, em formulação sintética, pelo inadimplemento contratual que suscita ao contratante inadimplente a obtenção de alguma vantagem patrimonial, seja pela alocação economicamente mais eficiente dos recursos que haveria de destinar ao cumprimento do contrato, seja pela conclusão de diverso vínculo contratual que lhe traz mais vantagens do que aquelas que adviriam do contrato originariamente celebrado (ARAÚJO, 2007, p. 745; SILVA, 2017, item 3.3). A ilustrar o questionamento relevante ao presente ponto do raciocínio, pode-se indagar: ao contratante que vem a se encontrar - deliberadamente ou não - em situação de inadimplemento eficiente pode ser imposta, além da obrigação de ressarcir as perdas e danos sofridas pelo credor (pré-fixadas ou não em cláusula penal compensatória), uma obrigação de restituir a vantagem que houver aferido em razão do inadimplemento contratual?

Trata-se de questão acentuadamente complexa e controversa, para a qual nenhuma corrente metodológica parece ter ainda fornecido resposta segura. ${ }^{25}$ Sem prejuízo a critérios mais específicos a serem elaborados pela doutrina, o percurso inafastável do intérprete há de ser a cuidadosa perquirição dos requisitos deflagradores do dever de restituir a partir da cláusula geral do dever de restituir contida no artigo 884 do Código Civil, destacadamente a obtenção à custa de outrem e a injustiça do enriquecimento. No tocante ao último ponto, incumbe ao intérprete promover juízo de merecimento de tutela da situação do contratante que aufere vantagem na sequência do enriquecimento. Tal juízo apresentará a relevante utilidade de possibilitar a consideração de circunstâncias fáticas específicas de cada caso concreto, podendo-se registrar, por exemplo, que a diversidade de setores ou ramos negociais não raramente afeta a concepção acerca da injustiça do enriquecimento obtido a partir do inadimplemento contratual.

Suponha-se que, em uma mesma hipótese fática, conclua-se pela configuração de enriquecimento sem causa e dano injusto. Por exemplo, imagine-se que certa atriz, pacifista, tem sua imagem utilizada de modo não autorizado por sociedade empresária na publicidade de um evento de MMA, esporte contra o qual ela se insurge em suas manifestações públicas por considerá-lo um incentivo à violência. A sociedade empresária, no exemplo citado, obteve enriquecimento sem causa, valendo-se da imagem da atriz sem autorização (lucro da intervenção). Além disso, contudo, o uso da imagem naquele contexto causou-lhe dano injusto, na medida em que afetou não apenas seu direito de imagem, mas também seu direito à identidade pessoal perante o público que a acompanha e a admira por sua bandeira pacifista. As pretensões restitutória e reparatória cumulam-se, sem se excluírem mutuamente, pois atendem a diferentes funções obrigacionais de fonte não negocial.

Surge aí, todavia, o problema de se avaliar em que medida a quantificação da restituição devida por lucro da intervenção interfere sobre a quantificação da pretensão reparatória, especialmente no caso de reparação sob a forma de indenização pecuniária. Alguns autores sugerem, nesse particular, que a restituição do lucro da intervenção apenas terá lugar quando o lucro auferido pelo interventor for superior ao dano

\footnotetext{
25 A ilustrar a referida dificuldade no âmbito da doutrina da análise econômica do direito, veja-se a posição de Fernando Araújo (2007, p. 747) acerca dos limites da eficiência do inadimplemento, distinguindo incumprimento oportunista de incumprimento não-oportunista: "Por outras palavras, do ponto de vista económico a recusa oportunista de cumprimento é essencialmente uma expressão de poder monopolista, e por isso em princípio é eficiente desencorajá-la, enquanto que o incumprimento não-oportunista resulta da constatação de que aquilo que eram condições contratuais favoráveis no momento da celebração do contrato deixaram de sê-lo no momento em que é exigível o cumprimento das obrigações contratuais - não se afigurando ser necessário desencorajá-lo desde que estejam reunidos os pressupostos de uma 'melhoria paretiana'”. Para uma análise econômica da mitigação do prejuízo, em particular no que tange à teoria do inadimplemento eficiente, v. Lopes (2013, p. 100 e ss.).
} 
causado à vítima e titular do direito (SAVI, 2012, p. 57). Tal perspectiva pode criar dificuldades práticas quando as pretensões reparatória e restitutória forem exercidas em momentos diversos, em procedimentos distintos ou ainda envolvendo naturezas distintas entre a vantagem auferida e a lesão sofrida (patrimonial $x$ moral). Ademais, a independência funcional das pretensões reparatória e restitutória sugere exatamente 0 contrário: fundando-se em razões substanciais distintas, não se excluiriam mutuamente em nenhuma medida.

Tal postulado esbarra, contudo, no dogma da subsidiariedade da pretensão restitutória do enriquecimento sem causa, que colocaria o intérprete de volta na delicada correlação entre valor da restituição e valor da indenização. O próprio conceito de lucro, para fins de configuração do lucro da intervenção, tem sido invocado nesse sentido. Isto porque, em realidade, o lucro somente pode ser aferido após o abatimento de todas as despesas atinentes ao desenvolvimento da atividade. Antes desse abatimento, talvez se possa falar em receita ou faturamento, mas certamente não em lucro, assim entendido o resultado final positivo após a dedução de todas as despesas em relação ao montante arrecadado - despesas que, em teoria, poderiam abranger o próprio valor da indenização paga à vítima no âmbito do exercício de pretensão reparatória. ${ }^{26}$ Daí porque a maior parte dos autores que se dedica ao tema conclui que a delimitação do lucro auferido pelo interventor pressupõe o prévio abatimento do montante porventura desembolsado a título de indenização pelo uso do bem ou direito alheio (COELHO, 1970, p. 8; SAVI, 2012, p. 121; CAMPOS, 1982, p. 52). A conclusão, que funcionaria como espécie de limite à cumulação das pretensões reparatória e restitutória, parece mais facilmente sustentável nas hipóteses em que o dano injusto assume natureza patrimonial tal qual o enriquecimento injustamente obtido. Sua aplicação, todavia, às hipóteses fáticas, em que a intervenção sobre bens ou direitos alheios gera dano injusto de natureza extrapatrimonial - como no exemplo da atriz lesada em sua identidade pessoal, além de seu direito de imagem -, pode produzir a sensação de que se está, com o perdão da expressão, subtraindo laranjas de maçãs. A quantificação da indenização em termos pecuniários não parece suficiente a colmatar as naturezas distintas do que se pretende funcionalmente produzir como consequência jurídica de uma dupla violação. Uma efetiva autonomia e cumulatividade das pretensões reparatórias e restitutórias necessita ser avaliada, cuidadosamente, sob essa perspectiva.

\section{Notas sobre a quantificação da obrigação de restituir o lucro da intervenção}

O ponto mais controvertido, na prática, em relação ao lucro da intervenção consiste na quantificação da restituição devida. A vinculação funcional da restituição do lucro da intervenção ao regime jurídico do enriquecimento sem causa aponta, em primeiro lugar, para a prevalência do enriquecimento efetivamente auferido pelo interventor como critério de quantificação. Afastam-se, com isso, eventuais juízos hipotéticos, privilegiando-se, ao revés, a investigação da concreta repercussão da intervenção sobre o patrimônio do

26 Ao comentar a quantificação dos lucros cessantes, Gisela Sampaio da Cruz Guedes (2011, p. 302-303) fornece útil definição do lucro como o faturamento abatido das despesas: "Se a finalidade de toda a reparação de danos patrimoniais é, de fato, fazer com que o lesado não fique numa situação nem melhor nem pior do que a que estaria se não fosse o evento danoso, então o julgador terá que ter um cuidado especial com a reparação dos lucros cessantes, para não deixar de computar, no cálculo da indenização, eventuais despesas operacionais, bem como outros gastos que o lesado teria em condições normais. A despeito de sua aparente dificuldade, esta assertiva é perfeitamente justificável - e decorre do próprio conceito de lucro (faturamento menos despesa)". Na jurisprudência, ver, em igual sentido, STJ, REsp. 710.376/RJ, $4^{a}$ T., Rel. Min. Luis Felipe Salomão, julg. 15/12/2009, publ. 02/02/2010. A decisão restou assim ementada: "Propriedade Industrial. Uso Indevido de Marca. Indenização por Direitos Materiais. Comprovação. Dissídio Jurisprudencial Configurado. Critério de Cálculo. 1. A falta de prequestionamento em relação aos arts. 331, I, do CPC e 208 da Lei 9.279/96, impede o conhecimento do recurso especial. Incidência da súmula 211/STJ. 2. No caso de uso indevido de marca, com intuito de causar confusão ao consumidor, o entendimento predominante desta Corte é que a simples violação do direito implica na obrigação de ressarcir o dano. Precedentes. 3. Conquanto os lucros cessantes devidos pelo uso indevido da marca sejam determinados pelo critério mais favorável ao prejudicado, conforme o art. 210, caput, da Lei 9.279/96, o critério de cálculo previsto na lei deve ser interpretado de forma restritiva, fazendo-se coincidir, nesse caso, o termo 'benefícios' presente no incido II, do art. 210, com a idéia de 'lucros' . 4. Recurso especial conhecido em parte e, nesta parte, provido". No voto, destacou o Relator: "Com efeito, conquanto os lucros cessantes sejam determinados pelo critério mais favorável ao prejudicado, pelo uso indevido de sua marca, não se pode interpretar a expressão "benefícios auferidos pelo autor da violação' de modo a calcular a indenização conforme o valor total auferido com os produtos vendidos. Esse não é o critério previsto na lei, que deve ser interpretado de forma restritiva, fazendo-se coincidir, nesse caso, o termo 'benefícios' com a idéia de 'lucros'. Ainda que as mercadorias tivessem sido produzidas e vendidas pelos próprios titulares do direito de propriedade industrial violado, os benefícios auferidos seriam menores do que o montante tido com a possível venda dos produtos, face os custos de produção, transporte, mão de obra e demais despesas fiscais." 
interventor, o que frequentemente indicará um valor distinto daquele referente ao mero preço médio de mercado para utilização do bem. ${ }^{27}$

A enunciação de critérios para a quantificação da obrigação restitutória a ser imposta ao interventor depende, nesse contexto, da sua compatibilidade com duas premissas fundamentais - a identificação do perfil funcional restitutório e a primazia do enriquecimento real (i.e., concretamente auferido pelo interventor). Da primeira premissa decorre a impossibilidade de consideração de critérios atinentes à promoção do perfil funcional reparatório, cujo escopo central consiste na recomposição da situação patrimonial ou pessoal da vítima de um dano injusto. O escopo central da função restitutória, diversamente, consiste na restauração de patrimônio injustificadamente incrementado, do que se depreende a incompatibilidade, a priori, de critérios relevantes na seara da responsabilidade civil para a compreensão do enriquecimento sem causa.

Da segunda premissa supramencionada (a primazia do enriquecimento real em oposição ao virtual ou hipotético) decorre a necessidade de formulação de critérios que auxiliem o intérprete na delimitação do enriquecimento concreta e injustificadamente obtido à custa do patrimônio do titular do direito explorado. O necessário esforço, portanto, parece consistir em uma autêntica tentativa de elucidação do pressuposto de obtenção à custa de outrem, o qual, conjugado com o requisito do enriquecimento, desempenha papel central para a delimitação do quantum debeatur.

Entre outros critérios já aventados em doutrina para a quantificação da obrigação restitutória tendo por referência a específica hipótese do lucro da intervenção, particular destaque merece a questão do nexo de causalidade. Imprescindível, nesse sentido, perquirir o grau de contribuição causal de cada um dos fatores concorrentes para a produção do enriquecimento do interventor (KONDER; SAAR, 2017, p. 153; MICHELON JR., 2007, p. 204). Trata-se, em suma, de identificar o concreto grau de contribuição da conduta própria do interventor e do direito explorado na cadeia causal de produção do lucro da intervenção (LINS, 2016, p. 189). O montante do enriquecimento que decorra da conduta do próprio interventor não pode, por certo, ser reputado obtido a partir de patrimônio alheio. ${ }^{28}$

Vale fazer menção, por fim, ainda em prol da elucidação de critérios para o cálculo do lucro da intervenção, ao critério da boa-fé ou má-fé subjetiva por parte do interventor (COHEN; SAAB, 2016, p. 143). Afirma-se, nessa linha de sentido, que, diante da ausência de critérios específicos para a quantificação do lucro da intervenção, resultaria mais compatível com o sistema positivo brasileiro o reconhecimento da relevância do referido critério subjetivo (KONDER; SAAR, 2017, p. 152-153). Aplicar-se-iam por analogia, assim, as previsões legais que elencam a boa-fé ou má-fé subjetivas do interventor como critério relevante para a quantificação de hipóteses específicas de restituição, como se verifica, por exemplo, na disciplina dos efeitos da posse em relação às benfeitorias (artigos 1.219 e 1.222 do Código Civil).

Tal linha de entendimento ostenta o relevante mérito de promover uma maior concretização da cláusula geral do dever de restituir (ao menos na modalidade de lucro da intervenção), em compatibilidade direta com critérios expressamente adotados pelo legislador para hipóteses específicas de restituição.

27 A partir de semelhante preocupação no sentido de não restringir o montante da restituição ao valor objeto de uso da coisa, afirma-se, embora com referência aos atributos de patrimonial e real do enriquecimento em sua acepção tradicional: "Se pensarmos o que é propriamente o enriquecimento sem causa no lucro da intervenção chegaríamos à conclusão de que ele deve partir do enriquecimento real, ou seja, o bem ou o direito apropriado ou consumido por outrem sem qualquer justificativa legal - essa parcela obrigatoriamente deveria ser restituída ao locupletado. Entretanto, quando o enriquecimento patrimonial for maior que o enriquecimento real, seria isso suficiente? Entra em discussão, após a restituição do enriquecimento real, a porcentagem a ser paga decorrente desta apropriação, no caso, a parcela do enriquecimento patrimonial, que será os efeitos do bem ou direito locupletado sobre o patrimônio do interventor" (KONDER, 2017, p. 152).

28 Carlos Nelson Konder e Patrick Saar (2017, p.153) trazem instigante exemplo: "Imagine-se, por exemplo, que A é um aluno de economia e, por algumas análises no mercado de capitais, encontre o momento perfeito para especular. Ele, desesperado em busca de capital, vai a diversos bancos. Contudo, por sua aparente inexperiência, não obtém nenhum recurso. A, então, maliciosamente, engana $B$ (de forma que, posteriormente, mostrou-se inescusável) e toma para si um montante de x e, finalmente, aplica o dinheiro. Em um intervalo curto, atinge-se a soma de 200x. A máfé dele, com base no critério anterior, já justificaria conceder a $\mathrm{B}$ um valor superior ao enriquecimento real (x). Justificaria, todavia, a devolução da integralidade do enriquecimento patrimonial obtido (200x)? Notamos, aqui, a imprescindibilidade do bem de B para a obtenção de todo o patrimônio de A, mas como poderíamos, dado o exemplo, dispensar a aguda destreza de A, seu próprio trabalho? O critério do grau de contribuição causal permitiria, nessas situações, considerar não apenas o ânimo do interventor, mas também os limites que necessitamos dar à 'noção rígida do nexo de causalidade"'. 
Aponta-se, contudo, a existência de risco subjacente a tal proposição teórica, uma vez que a expansão imoderada da relevância da má-fé subjetiva poderia traduzir, ainda que inconscientemente, a consagração de propósitos punitivos no interior do instituto do enriquecimento sem causa, com possível desvirtuamento da sua precípua função restitutória (LINS, 2016, p. 174). Em uma conjugação das preocupações inerentes a cada uma das referidas formulações teóricas - valorização do dado normativo versus afastamento de propósitos punitivos -, talvez se possa esboçar conclusão no sentido de que o critério da boa-fé ou máfé subjetiva do interventor fornece simplesmente mais um indício da (in)justiça do enriquecimento, cuja configuração final dependerá, em qualquer caso, da análise da compatibilidade da situação do interventor com a tábua axiológica constitucional. De resto, em disciplinas específicas, como aquela atinente aos efeitos da posse, os termos "má-fé" e "boa-fé" assumem sentidos muito próprios, talvez eles próprios merecedores de reformulação à luz de uma visão mais sistemática do direito brasileiro, consentânea com os valores consagrados em nossa Constituição.

\section{Conclusão}

Como visto ao longo deste breve estudo, o recurso à análise funcional das obrigações permite traçar relevante distinção entre a reparação do dano e a restituição do enriquecimento sem causa, no âmbito da qual se insere o lucro da intervenção. Tem-se, em síntese, uma nítida diferença de foco: enquanto a vedação ao enriquecimento sem causa visa à restituição do patrimônio do enriquecido ao estado em que deveria estar caso não houvesse ocorrido o fato gerador do enriquecimento injusto, a responsabilidade civil tem como função primordial a reparação integral do dano sofrido pela vítima (TERRA; GUEDES, 2015, p. 21-22).

Dessas distinções fundamentais decorrem, por um lado, a circunstância de o enriquecimento sem causa prescindir de qualquer empobrecimento por parte do titular do direito, e, por outro lado, o fato de a indenização ignorar, via de regra, eventuais reflexos patrimoniais positivos da conduta lesiva sobre o patrimônio do próprio causador do dano. Daí decorre a necessidade de se enquadrar a problemática do lucro da intervenção na seara do enriquecimento sem causa, desde que preenchidos os requisitos da cláusula geral do dever de restituir contida no artigo 884 do nosso Código Civil.

O enquadramento sistemático do lucro da intervenção como modalidade de enriquecimento sem causa traz consequências, quer no tocante ao reconhecimento da possibilidade de cumulação das pretensões referentes ao lucro auferido pelo interventor e ao dano sofrido pelo titular do direito, quer no tocante aos critérios de quantificação que devem ser compatíveis com o enquadramento da figura no campo do direito restitutório. O lucro da intervenção continua a ser um tema merecedor de investigação mais profunda em nossa doutrina, mas tais premissas permitem corrigir desvios de rota que vão se formando em nossa jurisprudência, na qual o lucro da intervenção vem constantemente "ocultado", de modo mais ou menos deliberado, sob a categoria dos lucros cessantes, categoria típica do direito da responsabilidade civil, funcionalmente distinto do direito restitutório.

\section{Referências}

ABREU, Luís Vasconcelos. A violação de direitos de personalidade pela comunicação social e as funções da responsabilidade civil. Recentes desenvolvimentos jurisprudenciais. Uma breve comparação lusoalemã. In: RAMOS, Rui Manuel de Mora et alii (Org.). Estudos em homenagem à Professora Doutora Isabel de Magalhães Collaço. Coimbra: Almedina, 2002. v. II.

ARAÚJO, Fernando. Teoria econômica do contrato. Coimbra: Almedina, 2007.

BARASSI, Lodovico. La teoria generale delle obbligazioni. 2. ed. Milano: Giuffrè, 1964. v. II.

BARBOSA, Mafalda Miranda. Reflexões em torno da responsabilidade civil: teleologia e teleonomologia em debate. Boletim da Faculdade de Direito de Coimbra, Coimbra, v. 81, p. 511-600, 2005.

CAMPOS, Diogo José Paredes Leite de. Enriquecimento sem causa e responsabilidade civil. Revista da Ordem dos Advogados, Lisboa: Ordem dos Advogados Portugueses, ano 42, p. 39-55, 1982. 
CAPEROCHIPI, José Antonio Álvarez. El enriquecimento sin causa. Madrid: Universidad de Santiago de Compostela, 1979.

CARBONNIER, Jean. Droit civil. Paris: PUF, 2004. v. II.

COELHO, Francisco Manuel Pereira. O enriquecimento e o dano. Coimbra: Almedina, 1970.

COHEN, Fernanda; SAAB, Rachel. Parâmetros de quantificação do lucro da intervenção. In: MONTEIRO FILHO, Carlos Edison do Rêgo (Org.). Problemas de responsabilidade civil. Rio de Janeiro: Revan, 2016. p. 119-152.

CORDEIRO, António Menezes. Tratado de direito civil português. Coimbra: Almedina, 2010. v. II. t.II. DÍEZ-PICAZO, Luis. Derecho de daños. Madrid: Civitas, 1999.

ESPÍNOLA, Eduardo. Garantia e extinção das obrigações: obrigações solidárias e indivisíveis. Atual. Francisco José Galvão Bruno. Campinas: Bookseller, 2005.

FERREIRA, Maria Teresa Taborda Rosa. A tutela dos direitos de propriedade industrial pelo enriquecimento sem causa. 2013. Dissertação (Mestrado em Direito). Faculdade de Direito da Universidade de Lisboa, Lisboa, 2013.

GALLO, Paolo. Arricchimento senza causa e quasi contratti (i rimedi restitutori). In: SACCO, Rodolfo (a cura di). Trattato di diritto civile. 2. ed. Torino: UTET, 2008.

GIANNOTTE, Claudia. Arricchimento senza causa. In: CENDON, Paolo (a cura di). Trattario di diritto civile: titoli di credito, gestione di affari, ripetizione di indebito, arricchimento. Milano: Giuffrè, 2014.

GOMES, Júlio Manuel Vieira. $O$ conceito de enriquecimento, o enriquecimento forçado e os vários paradigmas do enriquecimento sem causa. Porto: Universidade Católica Portuguesa, 1998.

GUEDES, Gisela Sampaio da Cruz. Lucros cessantes: do bom-senso ao postulado normativo da razoabilidade. São Paulo: Revista dos Tribunais, 2011.

KONDER, Carlos Nelson. Dificuldades de uma abordagem unitária do lucro da intervenção. Revista de Direito Civil Contemporâneo, São Paulo: RT, v. 13, n. 4, p. 231-248, out./dez. 2017.

KONDER, Carlos Nelson. Enriquecimento sem causa e pagamento indevido. In: TEPEDINO, Gustavo (Coord.). Obrigações: estudos na perspectiva civil-constitucional. Rio de Janeiro: Renovar, 2005. p. 369398.

KONDER, Carlos Nelson; SAAR, Patrick. A relativização do duplo limite e da subsidiariedade nas ações por enriquecimento sem causa. In: TEPEDINO, Gustavo; TEIXEIRA, Ana Carolina Brochado; ALMEIDA, Vitor (Coord.). Da dogmática à efetividade do direito civil. Belo Horizonte: Fórum, 2017. p. 147-156.

LARENZ, Karl. Derecho de obligaciones. Trad. Jaime Santos Briz. Madrid: Editorial Revista de Derecho Privado, 1958. t.I.

LEITÃO, Luís Manuel Teles de Menezes. O enriquecimento sem causa no direito civil: estudo dogmático sobre a viabilidade da configuração unitária do instituto, face à contraposição entre as diferentes categorias de enriquecimento sem causa. Lisboa: Centro de Estudos Fiscais, 1996.

LINS, Thiago Drummond de Paula. $O$ lucro da intervenção e o direito à imagem. Rio de Janeiro: Lumen Juris, 2016.

LOPES, Christian Sahb Batista. Mitigação dos prejuízos no direito contratual. São Paulo: Saraiva, 2013.

MALAURIE, Philippe; AYNĖS, Laurent; STOFFEL-MUNCK, Philippe. Droit des obligations. 7. ed. Paris: LGDJ, 2015.

MICHELON JR., Cláudio. Direito restituitório: enriquecimento sem causa, pagamento indevido, gestão de negócios. São Paulo: Revista dos Tribunais, 2007.

MIRAGEM, Bruno. Pretensão de repetição de indébito do consumidor e sua inserção nas categorias gerais do direito privado: comentário à Súmula 322 do STJ. Revista de Direito do Consumidor, São Paulo, v. 79, p. 385-402, jul./set. 2011. 
NANNI, Giovanni Ettore. Enriquecimento sem causa. 2. ed. São Paulo: Saraiva, 2010.

NORONHA, Fernando. Direito das obrigações. 4. ed. São Paulo: Saraiva, 2013.

PERLINGIERI, Pietro. O direito civil na legalidade constitucional. Trad. Maria Cristina De Cicco. Rio de Janeiro: Renovar, 2008.

SACCO, Rodolfo. L'arricchimento ottenuto mediante fatto ingiusto: contributo alla teoria della responsabilità estracontrattuale. Torino: UTET, 1959. Ristampa inalterata: Centro Stampa Università de Camerino, 1980.

SAVI, Sérgio. Enriquecimento sem causa e responsabilidade civil: o lucro da intervenção. São Paulo: Atlas, 2012.

SCHILLER, Cristiano O. S. B. O enriquecimento sem causa no contexto da teoria do fato jurídico. Revista de Direito Privado, São Paulo, v. 71, p. 279-291, nov. 2016.

SCHREIBER, Anderson; KONDER, Carlos Nelson. Uma agenda para o direito civil-constitucional. Revista Brasileira de Direito Civil, Rio de Janeiro, v. 10, n. 4, p. 9-27, out./dez. 2016.

SCHULZ, Fritz. System der Rechte auf den Eingriffserwerb. Archiv für die civilistische Praxis, Tübingen, 105. Bd., H. 1, p. 1-488, 1909.

SILVA, Clóvis Veríssimo do Couto e. A obrigação como processo. São Paulo: Bushatsky, 1976.

SILVA, Rodrigo da Guia. A qualificação funcional da pretensão restitutória à luz da vedação ao enriquecimento sem causa. 2017. Dissertação (Mestrado em Direito). Universidade do Estado do Rio de Janeiro, 2017.

SILVA, Rodrigo da Guia. Contornos do enriquecimento sem causa e da responsabilidade civil: estudo a partir da diferença entre lucro da intervenção e lucros cessantes. Civilistica.com, Rio de Janeiro, ano 5 , n. 2, p. 1-25, 2016.

SILVA, Rodrigo da Guia. Danos por privação do uso: estudo de responsabilidade civil à luz do paradigma do dano injusto. Revista de Direito do Consumidor, São Paulo, v. 107, p. 89-122, set./out. 2016.

SILVA, Rodrigo da Guia. Novas perspectivas da exceção de contrato não cumprido: repercussões da boa-fé objetiva sobre o sinalagma contratual. Revista de Direito Privado, São Paulo, ano 18, v. 78, p. 43-83, jun. 2017.

SOUZA, Eduardo Nunes de. Situações jurídicas subjetivas: aspectos controversos. Civilistica.com, Rio de Janeiro, ano 4, n. 1, p. 1-26, 2015.

TEFFÉ, Chiara Antonia Spadaccini de. A restituição do lucro da intervenção nos casos de violação aos direitos da personalidade: uma questão entre o enriquecimento sem causa e a responsabilidade civil. In: MONTEIRO FILHO, Carlos Edison do Rêgo (Coord.). Direito das relações patrimoniais: estrutura e função na contemporaneidade. Curitiba: Juruá, 2015. p. 35-68.

TEPEDINO, Gustavo et alii. Código Civil interpretado conforme a Constituição da República. 2. ed. Rio de Janeiro: Renovar, 2012. v. II.

TEPEDINO, Gustavo; SCHREIBER, Anderson. Código Civil comentado: direito das obrigações. São Paulo: Atlas, 2008.

TERRA, Aline de Miranda Valverde. Cláusula resolutiva expressa. Belo Horizonte: Fórum, 2017.

TERRA, Aline de Miranda Valverde; GUEDES, Gisela Sampaio da Cruz. Considerações acerca da exclusão do lucro ilícito do patrimônio do agente ofensor. Revista da Faculdade de Direito da UERJ, Rio de Janeiro, n. 28, p. 1-24, dez. 2015.

TERRÉ, François; SIMLER, Philippe; LEQUETTE, Yves. Droit civil: les obligations. 11. ed. Paris: Dalloz, 2013.

Recebido em: 17/04/2018

Aprovado em: 16/08/2018 